\title{
Specially Invited Opinions and Research Report of the International Water Law Project: Global Perspectives on the Entry into Force of the UN Watercourses Convention 2014: Part Two
}

\author{
Gabriel Eckstein \\ Texas A\&M University School of Law, gabrieleckstein@law.tamu.edu \\ Patricia Wouters \\ Robyn Stein \\ Georgina Mackenzie \\ Maria Querol
}

See next page for additional authors

Follow this and additional works at: https://scholarship.law.tamu.edu/facscholar

Part of the International Law Commons, and the Water Law Commons

\footnotetext{
Recommended Citation

Gabriel Eckstein, Patricia Wouters, Robyn Stein, Georgina Mackenzie, Maria Querol, Richard Paisley \& Salman M. Salman, Specially Invited Opinions and Research Report of the International Water Law Project: Global Perspectives on the Entry into Force of the UN Watercourses Convention 2014: Part Two, 17 Water Pol'y 162 (Gabriel Eckstein eds., 2015). Available at: https://scholarship.law.tamu.edu/facscholar/1180
}

This Article is brought to you for free and open access by Texas A\&M Law Scholarship. It has been accepted for inclusion in Faculty Scholarship by an authorized administrator of Texas A\&M Law Scholarship. For more information, please contact aretteen@law.tamu.edu. 


\section{Authors}

Gabriel Eckstein, Patricia Wouters, Robyn Stein, Georgina Mackenzie, Maria Querol, Richard Paisley, and Salman M.A. Salman 


\title{
Specially invited opinions and research report of the International Water Law Project: global perspectives on the entry into force of the UN Watercourses Convention 2014: part two
}

\author{
Gabriel Eckstein ${ }^{1}$ (Editor)
}

E-mail: gabrieleckstein@law.tamu.edu

\begin{abstract}
From the Editor-in-Chief, Dr Jerome Delli Priscoli: This is the second part of a research report on opinions of prominent international water lawyers from each continent on the potential impacts of the 1997 UN Convention on the Non-Navigational Uses of International Watercourses. The first part of the report was published in Water Policy 16(6).
\end{abstract}

Keywords: International water law; Watercourses Convention

\section{Introduction to the series}

The following compilation is reproduced and adapted from a series of essays that appeared in the blog of the International Water Law Project (www.internationalwaterlaw.org). The series was solicited in preparation for the coming into force of the 1997 UN Convention on the Non-navigational Uses of International Watercourses. The Convention had been pending for 17 years since its adoption by the United Nations General Assembly (UNGA) in 1997. On 19 May 2014, Vietnam became the 35th party to the treaty, bringing the total number of State Parties to 35, the minimum number of ratifications needed to bring that Convention into force.

In anticipation of this long-awaited occasion, during the summer of 2014, the International Water Law Project hosted a series of essays on its blog (www.internationalwaterlaw.org/blog/) from some of the most knowledgeable scholars and practitioners worldwide. The series provided unique perspectives and information on the implications of the Convention for international water law and the global

\footnotetext{
${ }^{1}$ Professor Eckstein is a member of the law faculty at Texas A\&M University, creator and director of the International Water Law Project, and editor of the International Water Law Project Blog.
}

doi: 10.2166/wp.2014.009

CC IWA Publishing 2015 
management of transboundary watercourses. The outcome was a fantastic, provocative, and timely compilation that offered readers both an introduction and unique insight into the Convention. It also offered readers the opportunity to participate in the discussion and offer their own perspectives and opinions by submitting comments on the various essays. While the essays have been included in the following compilation, the readers' comments can be found on the International Water Law Project Blog.

The International Water Law Project is itself a unique institution. Existing solely on the Internet, the website is one of the premier resources and clearing houses for information on international water law and policy. Its purpose is to educate and provide relevant resources to researchers and the public and to facilitate cooperation over the world's freshwater resources.

\section{Professor Patricia Wouters ${ }^{2}$ on considering China's approach to the UN Watercourses Convention - time to revisit?}

One of China's riparian neighbors, Vietnam, was the 35th country to ratify the 1997 UN Watercourses Convention (UNWC), catalyzing its entry into force on 17 August 2014. What does this mean for China and this region? While China voted against the UN Resolution adopting the UNWC in 1997, this does not tell the whole story. Instead, China's transboundary water resources' management must be considered within a broader context, and as part of a continuum of China's evolving approach to international law.

\subsection{Setting the context}

With 5,000 years of history, China has considerable experience in water resources' development. Yet China's diminishing quantities and qualities of fresh water pose serious challenges to the nation's burgeoning economic growth (China Water Risk website). In recent years, this has led the government to include 'water' in its 'Number One priority' annual policy documents, instruments that drive Chinese national policy actions. Premier Li Keqiang's 'war on pollution' has also resulted in a range of measures targeting water pollution, especially in urban areas and development hubs (China, 2014 No.1 Doc). These domestic initiatives will have a critical impact on China's transboundary water practice.

Situated as the upper riparian in some 40 major transboundary watercourses with 14 riparian nations (see Figure 1), China has adopted an approach to transboundary water resources' management consistent with its 'Five Principles of Peaceful Coexistence': mutual respect for sovereignty and territorial integrity, mutual non-aggression, non-interference in each other's internal affairs, equality and mutual benefit, and peaceful coexistence. Each of these principles aligns directly with core values of the UN Charter. Recently, President Xi Jinping commemorated the sixtieth anniversary of the five principles and reaffirmed China's commitment to furthering this approach with a view to building 'a new type of international relations and a better world of win-win cooperation' (Ministry of Foreign Affairs of China, 2014).

China already implements this foreign policy strategy, with proactive outreach across Asia, Europe, Africa, and Latin America, concluding an impressive array of mostly bilateral agreements. As just one example, during his Latin American visit (described as opening 'a new chapter in China-Latin American win-win cooperation' (Yushan, 2014)), in his address to Brazil's National Congress, President Xi spoke of the need for 'international

\footnotetext{
${ }^{2}$ Professor Wouters directs the China International Water Law Programme at Xiamen Law School, China. She can be reached at pkwoutersxiamen@hotmail.com.
} 


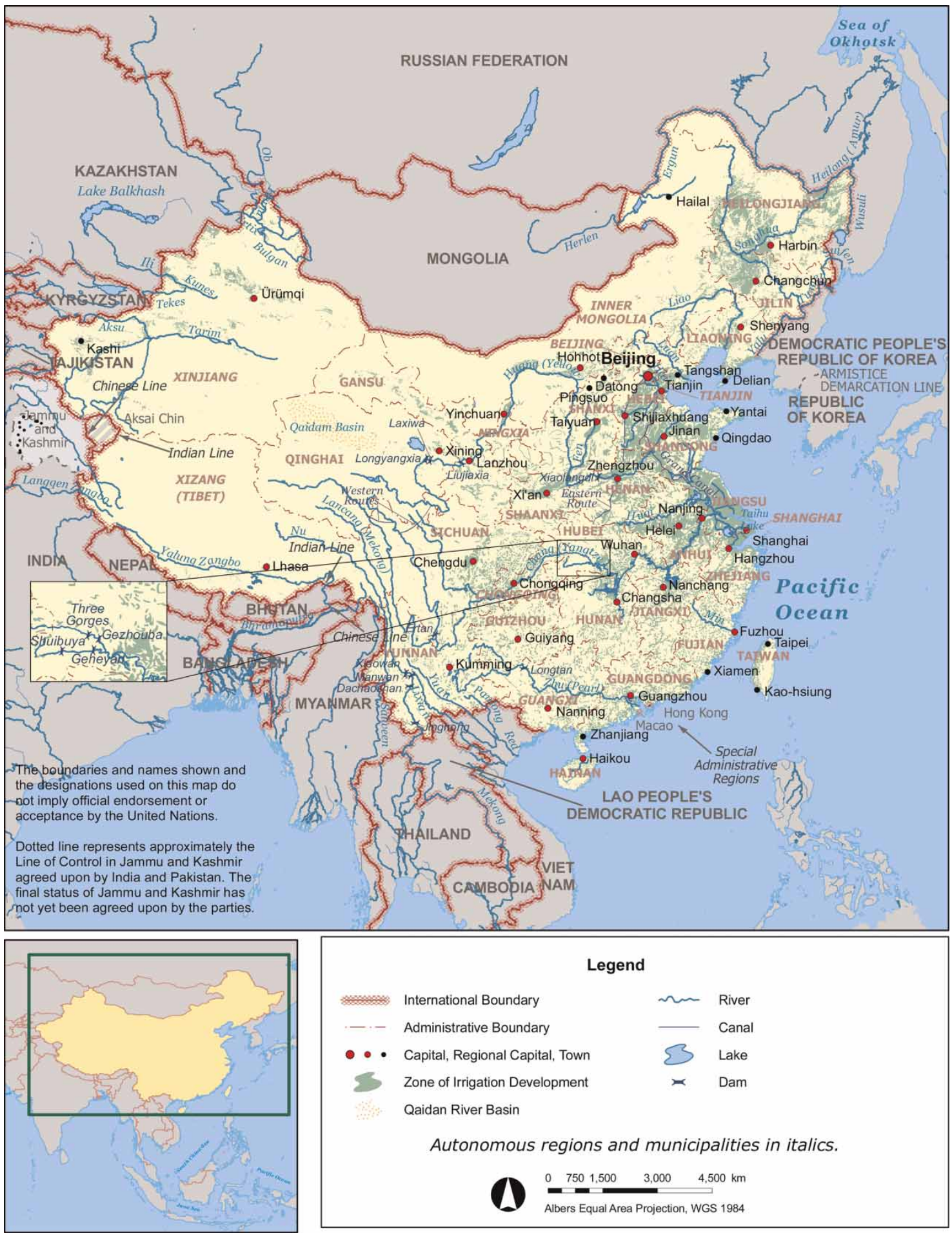

Fig. 1. China's transboundary waters. Source: Wouters \& Chen (2011). 
fairness and justice', and urged adherence to principles contained in the UN Charter (Ministry of Foreign Affairs of China, 2014; YouTube, 2014). While he reiterated the integral importance of national sovereignty and territorial integrity, he added that there must be due regard for the reasonable concern of others. Referring to China as a 'peace-loving nation', President Xi asserted that China opposed all forms of hegemony, adding that 'China cannot develop without the world and the world cannot develop without China'.

\subsection{China's position regarding the UNWC}

China's refusal to support the UN Resolution adopting the UNWC was aligned to its approach to international law. It was in this context that the Chinese delegate explained China's dissatisfaction with the text:

'First, it failed to reflect general agreement among all countries, and a number of states had major reservations regarding its main provisions. Second, the text did not reflect the principle of the territorial sovereignty of a watercourse state. Such a state had indisputable sovereignty over a watercourse which flowed through its territory. There was also an imbalance between the rights and obligations of the upstream and downstream states ... China could not support provisions on the mandatory settlement of disputes which went against the principles set out in the United Nations Charter... [China] favored the settlement of all disputes through peaceful negotiations. Accordingly... [China] voted against the draft resolution to which the draft convention was attached' (UNGA Press Release GA/9248, 1997).

Notably, however, during the deliberations leading to the Convention, China expressed strong support for many of the norms eventually included in the UNWC, especially the principle of equitable and reasonable use (UNGA Sixth Committee, 1996). Moreover, a recent study examining China's transboundary water treaty practice suggests that, in general, China's actions respect the approach of the UNWC (Chen et al., 2013). The research, however, also revealed that, while China embraces the duty to cooperate (as a general guiding principle) and supports the rule of equitable and reasonable use in its water-related treaties, these norms are often expressed in broad terms. Also, the mechanisms for transboundary cooperation provided for in China's treaties - rules of procedure, institutional mechanisms, and dispute settlement - are rather imprecise and focus primarily on technical issues. In addition, while the treaty practice lacks any compulsory or third-party dispute-settlement provisions, such an approach is consistent with China's view that differences should be managed through consultation, dialogue and negotiations.

\subsection{Contemporary transboundary water issues involving China - the case of the Mekong}

A recent article in the Financial Times (Clark, 2014) highlights China's upstream dilemma - how can China be the 'good neighbor' on the Mekong? China is only a dialogue partner under the Mekong Agreement, with observer status at Mekong River Commission (MRC) meetings. However, under an agreement with the MRC, China provides the Commission hydrological data on its portion of the river (see Figure 2). Nevertheless, downstream riparians recently alleged that China's dams were responsible for downstream flooding (December 2013) and scarcity (February 2014).

Without clear rules of procedure (such as those set forth under the UNWC and the Mekong Agreement), China's duty to cooperate lacks normative traction.

China has a unique opportunity in the field of transboundary waters for consolidating its emerging role as a 'good neighbor' that seeks 'win-win' solutions. Improved procedural rules and dispute-avoidance 


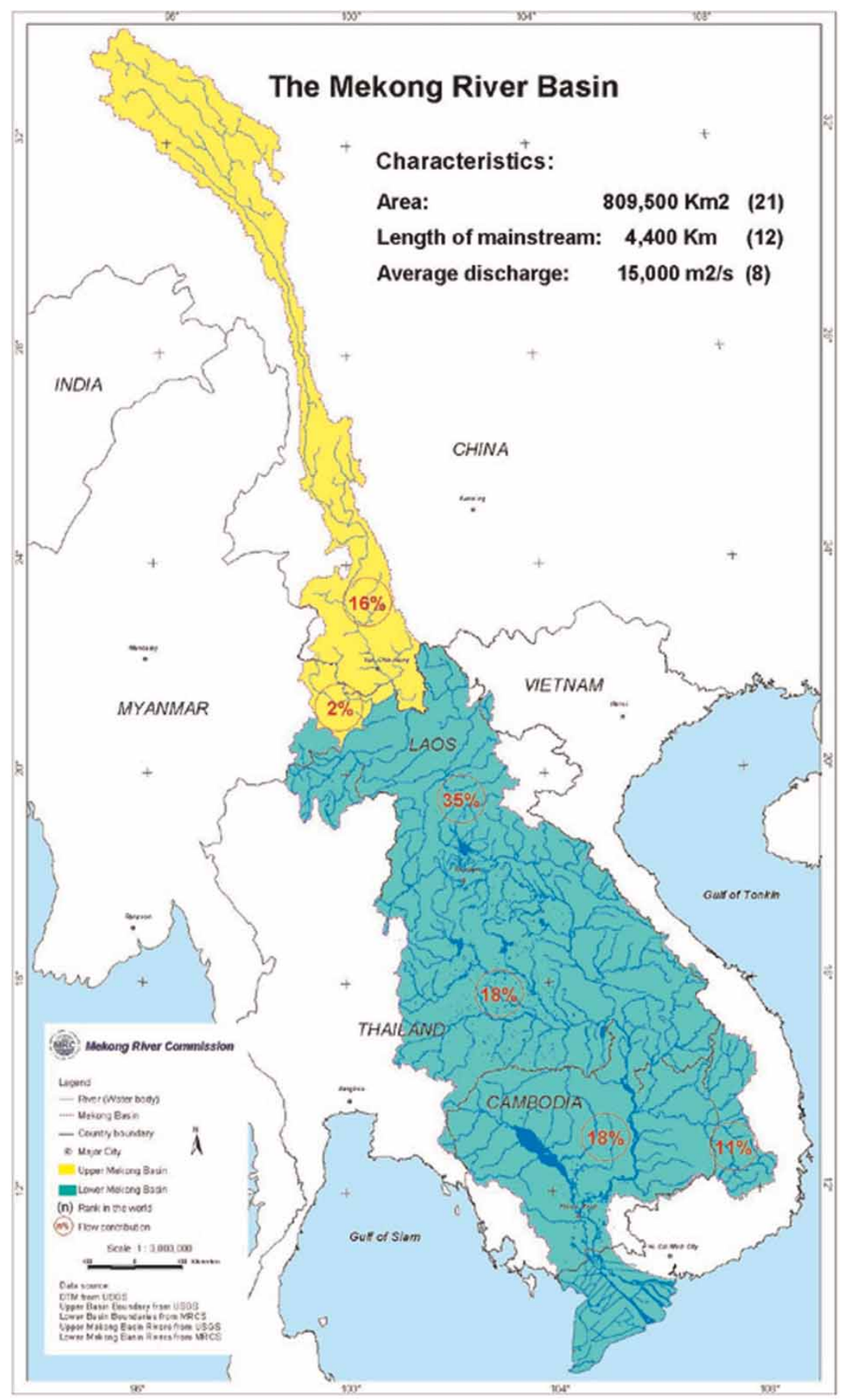

Fig. 2. The Mekong River Basin. Source: Ti Le-Huu \& Lien Nguyen Duc. 
mechanisms, developed to meet the regional context, could facilitate improved transboundary cooperation. With its considerable technical expertise, China could devise its own 'people-to-people' approach for enhanced transboundary cooperation.

\subsection{China's future approach to transboundary waters - the need for consolidation, including revisiting the UNWC as a framework instrument}

Things are changing. China is now well placed to develop its approach to transboundary water cooperation in ways that match its global foreign policy strategy. The UNWC, as a multilateral framework instrument, offers a range of rules and processes that China could adapt to meet its diverse transboundary issues in ways that demonstrate China's role as the 'good neighbor'. By incorporating some of the provisions and processes included in the UNWC in its existing and future treaty and state practice, China could move forward in this field. China appears to be heading in this direction, as demonstrated by its recent 2013 Declaration with Kazakhstan, which builds on past bilateral treaty practice and enlarges the Sino-Kazak joint commission's remit to include work on water allocation.

Borrowing from the UNWC, China could also find legal approaches that contribute to its 'war on pollution', in the transboundary context, by introducing more detailed substantive and procedural rules aimed at water pollution. In this regard, China might also take inspiration from the UNECE Convention on the Protection and Use of Transboundary Watercourses and International Lakes (1992). China's support for the UN (generally), coupled with its currently evolving approach to international law, provides compelling reasons for China to revisit the guidelines provided for in these two UN global water conventions.

China's emerging role in international development can also serve to enhance its approach to transboundary water cooperation. For example, China's new 'peace-through-development' agenda with India (Cohen, 2014) could help to build upon the series of recent transboundary water agreements between the two countries (Ramachandran \& Krishnan, 2014).

China's commitment to environmental protection (evidenced in China's participation in a broad range of multilateral environmental agreements, such as the RAMSAR Wetlands Convention (Convention on Wetlands of International Importance (RAMSAR Convention), 1975), Convention on Biological Diversity (1993), Climate Change Convention (UN Framework Convention on Climate Change, 1994), and Convention on Desertification (UN Convention to Combat Desertification, 1996)) also provides opportunities for consolidating its approach to transboundary water cooperation.

Realizing the 'Chinese dream' is an ambitious goal. The peaceful management of China's considerable transboundary water resources, in ways that are mutually beneficial to China and its riparian neighbors, must be part of this major undertaking.

\section{Professor Gabriel Eckstein ${ }^{3}$ on the implications of the UNWC for groundwater resources}

With Vietnam's accession to the 1997 UNWC, the global community has taken an important step toward cooperative riparian management of transboundary waters. Although most scholars and

\footnotetext{
${ }^{3}$ Professor Eckstein is a member of the law faculty at Texas A\&M University, director of the International Water Law Project, and editor of the International Water Law Project Blog. He can be reached at gabrieleckstein@law.tamu.edu.
} 
UNWC parties have focused on the surface water implications of the Convention, there is another critical component of the instrument that should not be neglected. The UNWC applies to many aquifers worldwide. The purpose of this essay is to consider the scope of the Convention in relation to groundwater resources and place it in the context of emerging international law for transboundary aquifers.

\subsection{Groundwater - a hidden treasure}

Groundwater is the world's most extracted natural resource. It provides approximately $45 \%$ of humanity's freshwater needs for everyday uses, such as drinking, cooking, and hygiene, and $24 \%$ of water used in irrigated agriculture (Margat \& van der Gun, 2013).

Not surprisingly, groundwater is highly transboundary. While 276 international watercourses traverse the world's land areas, an ongoing study identified 448 aquifers and aquifer bodies traversing international political boundaries (International Groundwater Resources Assessment Centre (IGRAC), 2012) (see Figure 3). In places such as the Middle East, North Africa, and the Mexico-USA border, transboundary aquifers serve as the primary or sole source of available fresh water for human and environmental sustenance.

Despite their importance, transboundary aquifers have been comparatively ignored in cross-border water management and treaty development. While thousands of agreements have been forged for transboundary rivers and lakes, only a handful directly apply to aquifers that traverse international frontiers. As one of the few international instruments to address this topic, the UNWC provides critical recognition of the important role groundwater resources play in human progress and development, as well as the need to establish principles of law governing this 'hidden' but valuable natural resource.

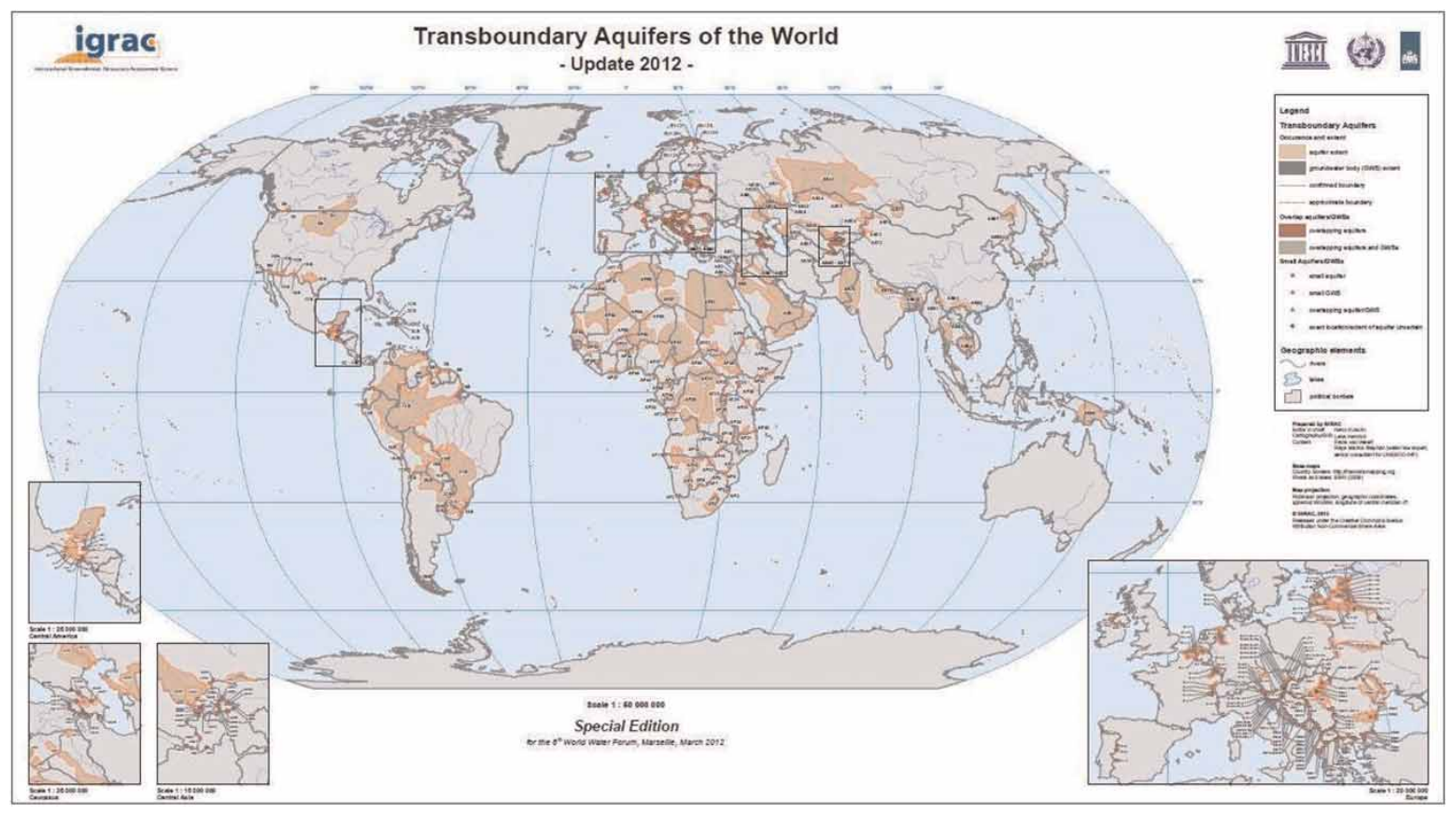

Fig. 3. Transboundary aquifers of the world-2012. Source: International Groundwater Resources Assessment Centre (IGRAC) (2012). 


\subsection{Applicability of the UNWC to groundwater resources}

Although the UNWC clearly applies to many of the world's groundwater resources, it is important to delineate precisely which aquifers are included and excluded from the rubric of the Convention. The UNWC defines 'watercourse' to mean 'a system of surface waters and groundwaters constituting by virtue of their physical relationship a unitary whole and normally flowing into a common terminus' and an 'international watercourse' as 'a watercourse, parts of which are situated in different States'. Parsing out this phraseology reveals a number of important qualifications.

For an aquifer to fall within the scope of the UNWC, it must be a part of a 'system of surface waters and groundwaters'. Use of the 'system' criterion in the definition implies an interrelationship between multiple and interlinked water bodies. This assessment is supported and complemented by the subsequent definitional language that emphasizes the 'physical relationship' and 'unitary whole' of the system, and the 'common' characterization of a terminus. Hence, solitary transboundary aquifers - such as independent fossil aquifers and rain-fed aquifers - are presumptively excluded from the scope of the UNWC.

It is noteworthy that subsequent to drafting the principles for the UNWC, the UN International Law Commission (ILC) submitted a Resolution on Confined Transboundary Groundwater in which it commended states to be guided by the principles of its work product in regulating independent and hydraulically unrelated transboundary groundwater resources (UNILC, 1994). This progressive recommendation was not incorporated into the UNGA's final version of the UNWC.

In addition, a textual reading of the two definitions suggests that the Convention applies where the transboundary character exists in any part of the system. Hence, a domestic aquifer is subject to the UNWC if it is hydraulically connected to a transboundary river. Similarly, an internal river would be bound by the terms of the Convention if it is linked to a transboundary aquifer. This latter scenario, however, may be subject to debate. In its Thirty-Second Session Report during its preparatory work to the UNWC, the ILC asserted that 'the main stem of a river traversing or forming an international boundary' is the 'core' of a watercourse. Additionally, Ambassador Chusei Yamada, who served on the ILC during the drafting of the UNWC and later as Special Rapporteur for the ILC's Draft Articles on the Law of Transboundary Aquifers (Draft Articles), explained to this author in a private conversation that in its deliberations the ILC, and later the UNGA, never contemplated applying the Convention where the transboundary character of the system could not be found in a surface water body. Given that the qualification has yet to be considered in state practice, it remains unclear how broadly it may be interpreted.

Another criterion affecting the UNWC's applicability to certain groundwater resources is the phrase 'flowing into a common terminus'. The criterion intimates that the interlinked water resources must flow toward the same end-point to be subject to the Convention's regime. The directional flow of rivers and lakes, however, is generally described in two dimensions (from point $\mathrm{X}$ to point $\mathrm{Y}$ ). In contrast, groundwater flow is defined in three dimensions because its movement is dependent on local geological conditions, which can vary throughout the aquifer. As a result, groundwater can flow toward a disparate terminal point from that of a related surface water body. Moreover, while aquifers do sometimes terminate at a single point, such as at a spring, it is more common for aquifers to discharge over an extended geographical area along the entire edge of the aquifer. Accordingly, the Convention does not apply to aquifers that do not share a common terminus with hydraulically connected rivers and lakes (see Figure 4).

In summary, the UNWC does apply to groundwater resources. However, the Convention's definitions narrow its relevance to domestic and transboundary aquifers that are hydraulically linked to a transboundary river or lake and that flow into a common terminus. They may also apply to transboundary aquifers that are 


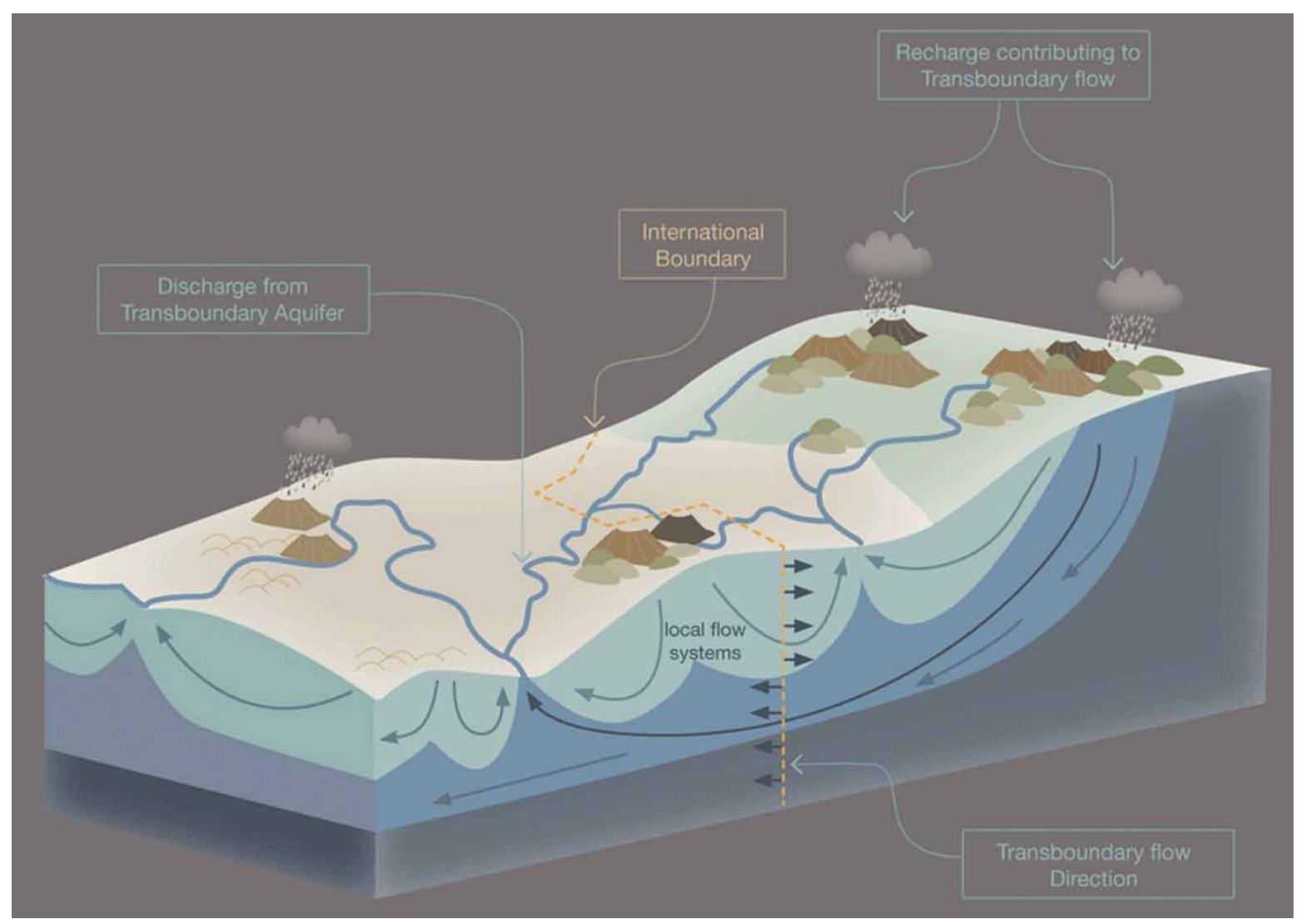

Fig. 4. Model of a transboundary aquifer. Source: UN Watercourses Convention Online Users Guide.

hydraulically linked to an internal water body, so long as the interrelated surface and subsurface waters flow into a common terminus. All other aquifers are excluded from the Convention's regime (Eckstein, 2005).

\subsection{UNWC, transboundary aquifers, and international law}

While the UNWC is widely regarded as codifying customary international law, it draws almost exclusively from state practice related to the management and allocation of transboundary rivers and lakes. This perspective is understandable as the bilateral and multilateral cooperative experience over transboundary groundwater resources is scant in comparison. Nevertheless, many of the norms contained in the UNWC are equally (or, at least, similarly) applicable to transboundary aquifers.

A 2011 study suggests that the customary responsibilities most conspicuous in state practice include the substantive obligations of equitable and reasonable utilization and of no significant harm (Eckstein, 2011). The study also recognizes the existence of accepted procedural duties, including regular exchange of data and information, generation of supplemental data and information through continuous monitoring and related activities, and prior notification of planned activities. The latter obligation is considerably more general and less developed procedurally than is contained in the UNWC. Principles contained in the UNWC, but which have yet to arise in state practice for transboundary aquifers, include norms related to ecosystem protection and pollution prevention, cooperative management mechanisms, and the settlement of disputes. 
In addition, the study identifies groundwater-specific concepts that, while logical, have yet to emerge in state practice, including obligations related to protecting recharge and discharge zones.

In 2002, the UNGA tasked the UNILC with drafting principles of law for transboundary aquifers based on trends in state practice and customary norms. The resulting Draft Articles are now before the UNGA (Eckstein \& Sindico, 2014). While the Draft Articles were modeled largely on the UNWC, there are a number of noteworthy differences. The UNWC applies to certain transboundary and some domestic aquifers as discussed above. In contrast, the Draft Articles apply to all transboundary aquifers, regardless of whether they are hydraulically linked to any other water body (surface or subsurface), and to domestic aquifers that are hydraulically related to a transboundary aquifer. In addition, the Draft Articles are tailored specifically for transboundary aquifers and include references and principles related to protecting recharge and discharge zones, ensuring the functioning of aquifers, and aquiferrelated monitoring activities. If the Draft Articles proceed toward an independent legal instrument, which is yet uncertain, the Draft Articles and UNWC will have to be harmonized.

\subsection{Conclusion}

The coming into force of the UNWC is a significant milestone in the evolution of international water law. While the Convention's applicability to certain of the world's groundwater resources may be limited, its growing acceptance and implementation signify the global community's broadening commitment to manage and utilize transboundary freshwater resources through peaceful and cooperative means. It also recognizes and affirms transboundary groundwater resources as a legitimate topic of international law.

\section{Robyn Stein and Georgina Mackenzie ${ }^{4}$ on the implication of the entry into force of the UNWC for Southern African states}

The Revised Protocol on Shared Watercourses (Protocol) of the Southern African Development Community (SADC) (2000) came into force in 2003. The original Protocol, concluded between SADC Member States (Figure 5) in 1995, was revised to ensure that it reflected those of the then-pending 1997 UNWC. With a few notable exceptions, numerous provisions of the Revised Protocol have identical counterparts in the UNWC. As South Africa and Namibia are the only SADC states to have ratified the UNWC, it must be asked whether the entry into force of the UNWC will have any impact on the implementation or content of the SADC Protocol, and whether other SADC states might now be motivated to accede to the Convention.

\subsection{Notable differences between the UNWC and the Protocol}

Despite numerous Protocol provisions mirroring the UNWC, there are two fundamental differences between the instruments.

3.1.1. Dispute-resolution mechanisms. Under Article 7 of the Protocol, Member States must 'strive to resolve' disputes relating to the implementation, interpretation, or application of the Protocol amicably.

\footnotetext{
${ }^{4}$ Ms Stein is director and attorney with Edward Nathan Sonnenberg, Inc. in South Africa where she specializes in water law and policy. She can be reached at rstein@icon.co.za. Ms Mackenzie is a candidate attorney working with Ms Stein.
} 


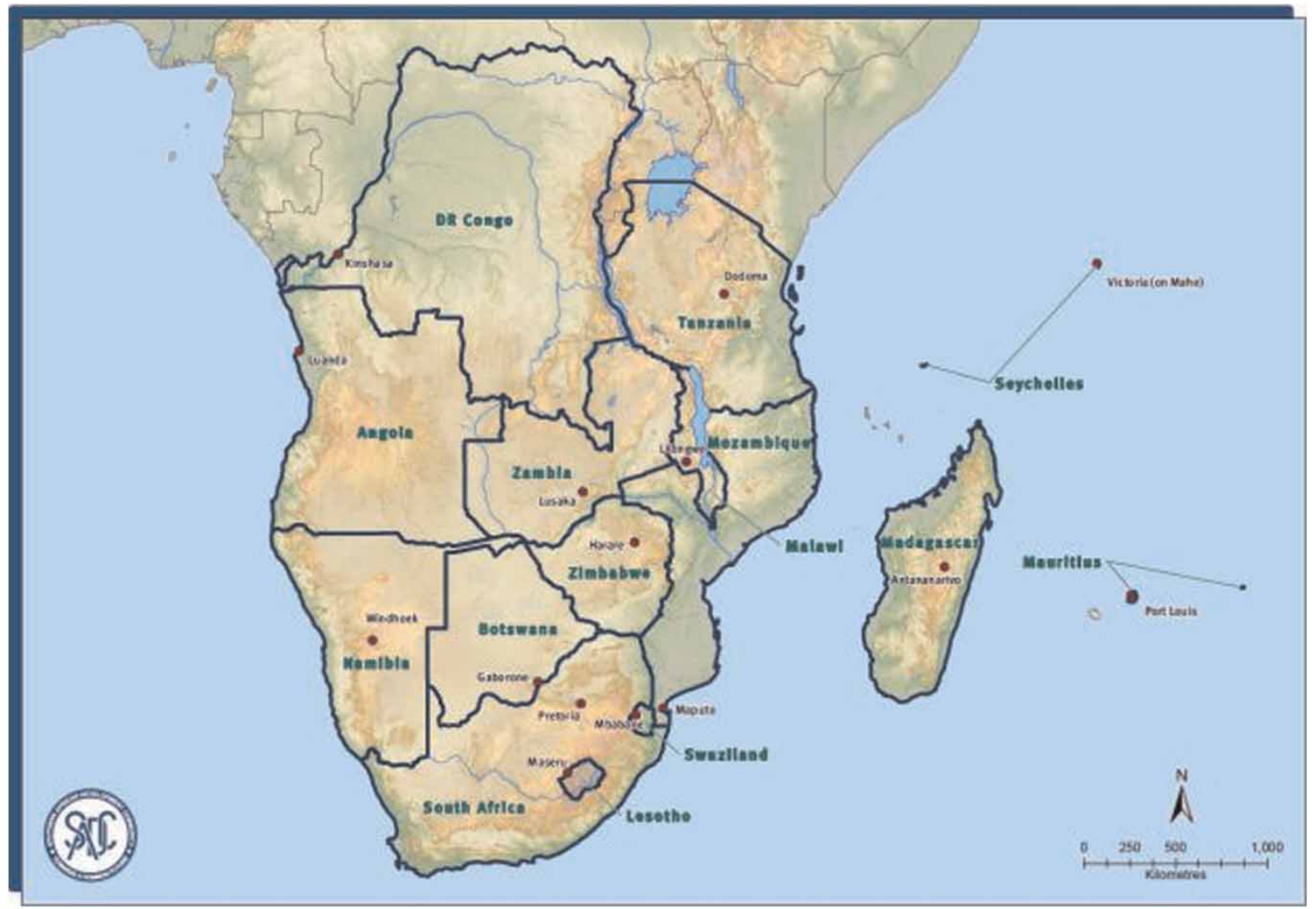

Fig. 5. Countries in the Southern African Development Community. Source: Southern African Development Community Member States: http://www.sadc.int/member-states/.

Otherwise, disputes must be referred to the SADC Tribunal. In contrast, the corresponding article in the UNWC, Article 33, offers numerous dispute-settlement options, beginning with negotiations, followed by mediation or conciliation through a third party, the use of joint watercourse institutions, submission to arbitration, and adjudication by the International Court of Justice (ICJ).

Furthermore, under Article 33(3) of the UNWC, if the parties have not settled their dispute within 6 months, any party can unilaterally initiate impartial and compulsory fact-finding procedures. A 'Fact-finding Commission' comprising members nominated by all parties is thereafter required to produce a report setting out findings and recommendations for an equitable solution. While the parties must consider such findings and recommendations in good faith, scholars suggest that they are not bound by the pronouncement (Rieu-Clarke \& Rocha Loures, 2009). In this sense, the Commission may be characterized as 'compulsory conciliation'. This fact-finding procedure is one of the significant provisions of the UNWC, and yet the most notable absence from the Protocol.

3.1.2. 'Equitable utilization' principle vs the 'no harm' obligation. Both the UNWC and the Protocol oblige watercourse states to utilize shared watercourses in an 'equitable and reasonable manner' vis-àvis other riparians. Whether or not such use is reasonable and equitable depends on a non-exhaustive number of social, economic, and environmental factors listed in both instruments. Each instrument 
(Protocol Article 3(10)(a); UNWC Article 7(1)) obliges parties to take 'all appropriate measures to prevent significant harm to other watercourse states'. The legal relationship between these two principles is of extreme importance, and the precedence of one specific principle over the other has been deemed to have wide-ranging implications (Malzbender \& Earle, 2013).

It is now widely recognized that the UNWC gives precedence to the 'equitable utilization' principle over the 'no significant harm' obligation and it is considered the 'cornerstone' of the UNWC. This position is evident in the International Court of Justice's endorsement of this preference in the Gabčikovo-Nagymaros Project case (Hungary/Slovakia) (ICJ) (1997). In contrast, Protocol Article $3(10)(b)$ states that where significant harm is nonetheless caused to another watercourse state, the responsible state must take appropriate measures to eliminate or mitigate such harm having due regard for the provisions of Article 3(10)(a), which embodies the Protocol's no-harm obligation. Therefore, some have interpreted the Protocol to give preference to the no-harm obligation over the equitable utilization principle (Malzbender \& Earle, 2013).

While it may be argued that some Protocol provisions have been poorly drafted, two arguments support the precedence of the no-harm obligation in the Protocol.

Despite the express reference to the UNWC, the Protocol was never intended to mirror the UNWC. This is evident in historical drafts and instruments as well as other notable differences between the two instruments. Moreover, while the Protocol provides a substantial definition for 'significant harm', the UNWC contains no comparable characterization. Arguably, inclusion of this definition in the Protocol indicates that the drafters intended to harness the objective nature of this definition and its factual importance to the complex set of SADC transboundary water resource issues. As such, they sought to ensure that the no-harm obligation prevails over equitable and reasonable use.

Stephen McCaffrey, a leading scholar of international water law, contends that the preference in the Protocol for the no-harm obligation prevents SADC states from developing or using shared watercourses in a manner that causes significant harm to other watercourse states - even if such use or development were equitable and reasonable - unless the latter states consent to such use and development (McCaffrey, 2001). While this precedence in the Protocol favors downstream watercourse states, the UNWC's structure has the converse effect.

\subsection{Accession to the UNWC by other SADC member states}

As the Protocol is largely based on the framework of the UNWC, more SADC states might have been expected to have ratified the Convention by now. However, only Namibia and South Africa have joined the UNWC. Two reasons might explain the hesitancy of the remaining SADC states toward the Convention.

3.2.1. Questioning the relevance of the UNWC. Article 3(1) ensures that pre-existing watercourse agreements and states' rights and duties arising from such agreements (including the Protocol) remain unaffected by accession to the UNWC. All that the Convention requires is that states "consider harmonizing such agreements with the basic principles' of the UNWC. Furthermore, Article 33(1) gives precedence to regional machinery where it exists (such as the Protocol) for dispute resolution. Therefore, SADC states may feel that there is no urgency to accede to the UNWC.

3.2.2. Redundancy of instruments. The UNWC was intentionally designed as a framework convention with basic principles and rules that can be used flexibly and inform inter-state watercourse agreements. 
It was always intended to be supplemented by more detailed agreements. The Protocol, with its connection to the UNWC, adopted a similar framework approach. Therefore, some SADC states might view the UNWC as a duplication of the Protocol and regard membership in the Convention as a redundant undertaking (Rieu-Clarke, 2007).

\subsection{Effect of entry into force of the UNWC on implementation of the Protocol}

The origins of the UNWC reinforce one of the UNWC's primary purposes - to codify and progressively develop the content of customary international water law (UNGA Resolution 2669, 1971). McCaffrey asserts that the UNWC strengthens and clarifies customary international law principles governing international watercourses through its status as the most authoritative statement of the norms of international water law, including the principle of equitable and reasonable utilization (McCaffrey, 2001). SADC states opposed to the precedence of the no-harm obligation in the Protocol might use the UNWC to evidence customary international law's preference for equitable and reasonable use. This could create discord among SADC members and undermine the founding principles of both the UNWC and the Protocol.

In contrast, SADC states that support the preference for the no-harm obligation in the Protocol might contend that the UNWC merely codifies the normative principles of customary international law without defining the core and content of the prioritization of equitable and reasonable use over the no-harm obligation. At issue is the extent to which the UNWC provides practicable guidance on how the precedence will inform the drafting of effective shared watercourse agreements between states. Similarly, SADC members may assert that notwithstanding the precedence of equitable and reasonable use in the UNWC, alignment between the Protocol and the UNWC is unachievable until the UNWC offers more guidance on how its normative principles can be given practical effect (Salman, 2001). This is particularly evident where competing interests arise in circumstances of hydro-political conflict and dire water scarcity, both of which are ongoing challenges within the SADC region.

This argument is reinforced by the nature of the UNWC as a framework instrument designed to inform the structure of local and regional watercourse agreements. By allowing pre-existing agreements to remain intact (Article 3(1)) and permitting adjustments to Convention provisions where required by local circumstances (Article 3(5)), the UNWC can be tailored to specific watercourses. This feature, however, may make some SADC states uncomfortable with the extent to which member states can depart from the UNWC's norms, and the degree to which such departures and varied interpretations can be effectively managed.

\subsection{Conclusion}

Until more SADC states accede to the UNWC (which appears unlikely in the near future), the coming into force of the Convention will have limited effect on the Protocol. The UNWC will provide interpretive guidance to those Protocol provisions that incorporate the normative principles of customary international law embodied in the UNWC. In the absence of constructive and inclusive engagements between SADC states and a central agency responsible for managing and implementing the UNWC, it is unlikely that the UNWC will have a tangible influence on the Protocol for some time to come. 


\section{Dr Maria Querol ${ }^{5}$ on the UNWC and South America}

\subsection{Introduction}

Although the 1997 UNWC has finally entered into force, not one South American country is among its State Parties. While Brazil, Chile, Uruguay, and Venezuela voted in favor of its adoption at the UN General Assembly, Argentina, Bolivia, Colombia, Ecuador, Paraguay, and Peru all abstained. Paraguay and Venezuela were the only states from the region to sign the Convention, in 1997 and 1998, respectively. Nevertheless, neither has made any attempt to ratify it.

Many arguments have been presented to justify this flagrant absence, mainly focusing on the concern of South American states regarding challenges to their sovereignty over water resources flowing through their territories. However, this is not the only factor to be considered when analyzing the region's position on this topic.

\subsection{Multilateral transboundary water treaties of South America}

South American (see Figure 6) states have a history of concluding international treaties to regulate the management of their shared watercourses. This long-standing tradition favors the implementation of specific mechanisms and international water law norms over more general regimes. While most of these agreements are bilateral, there are four exceptions: the Treaty of the River Plate Basin (1969), the Agreement on the Guarani Aquifer (2010), the Treaty for Amazonian Cooperation (1978), and the Agreement constituting the Tri-National Commission of the Pilcomayo River Basin (1995).

The Plate Basin Treaty entered into force for Argentina, Bolivia, Brazil, Uruguay, and Paraguay on 14 August 1970. It operates as an umbrella for other more specific agreements, both bilateral and multilateral, that have been concluded with regard to particular transboundary watercourses within the basin. Article VI of this agreement foresees the possibility that its Contracting Parties may conclude specific, partial, bilateral, or multilateral agreements designed to develop the basin. Accordingly, the Guarani Aquifer Agreement was concluded within the framework of the Plate Basin Treaty. Thus, the basin is regulated with an integrated approach, both from a general and a more specific standpoint.

Transboundary watercourses are regarded in the region as shared natural resources. This view was particularly emphasized by both Argentina and Uruguay in the 1975 River Uruguay Statute (Statute of the River Uruguay, 1975) and reaffirmed in 2010 in the Pulp Mills case before the ICJ (Pulp Mills on the River Uruguay (Argentina v. Uruguay) (ICJ), 2010). In this regard, Argentina argued in its memorial to the Court that ' $[t]$ he shared nature of the River Uruguay is also apparent from the fact that obligations are imposed on Argentina and Uruguay at an international level. The 1975 River Uruguay Statute is actually a repository for th[ose] international obligations'. Those obligations comprise the rules of no significant harm, equitable and reasonable use, and prior notification. It is important to bear in mind that these general norms are only applicable to the use and protection of shared natural resources as long as the states sharing the resource have not implemented a more specific conventional regime. Accordingly, Argentina also declared that while the River Uruguay Statute had been concluded 22 years before the UNWC was adopted by the UNGA, 'the Statute provides for the

\footnotetext{
${ }^{5}$ Dr Maria Querol is an international law consultant with a vast background in international water law. She can be reached at maria.querol@gmail.com.
} 


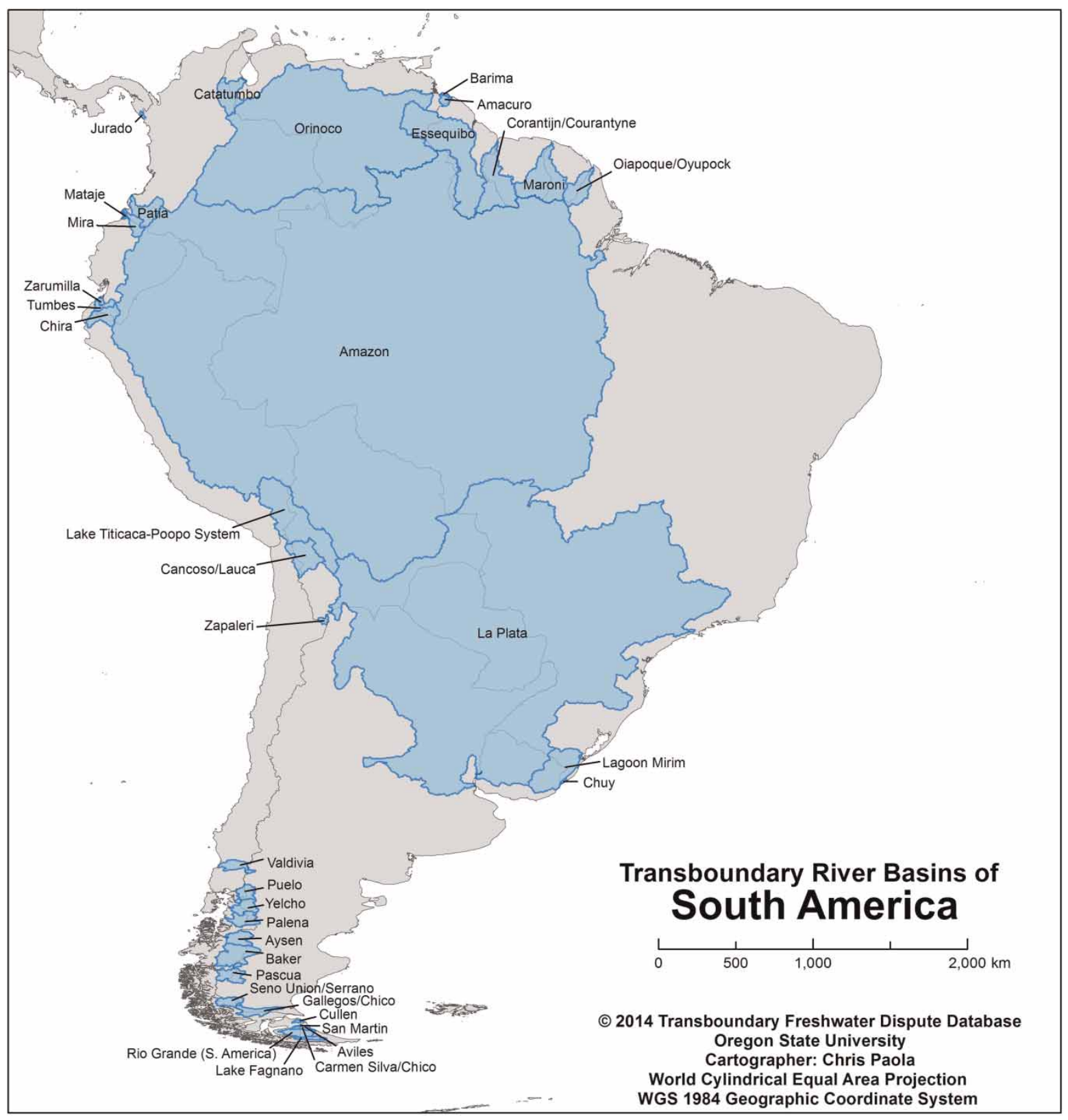

Fig. 6. South America international basins. Source: Transboundary Freshwater Dispute Database Oregon State University (2014).

establishment of a system of co-operation which is far more rigorous than that laid down by the Convention'.

The Amazon Cooperation Treaty was adopted by Bolivia, Brazil, Colombia, Ecuador, Peru, Suriname, and Venezuela to promote equitable and mutually beneficial results in the Amazon 
territories under their respective jurisdictions. It entered into force on 12 August 1980. The no harm rule and the reasonable and equitable principle are enshrined in Article I of the agreement. The no harm rule is also implicit in Article XVI as it stipulates that the decisions and commitments adopted by the State Parties to the treaty shall not be to the detriment of projects and undertakings executed within their natural territories, in accordance with international law. In addition, Article $\mathrm{V}$ prescribes the rational utilization of the water resources of the Amazon System. Periodic exchange of information between all the State Parties is also provided for in Articles I, VII and XI.

By virtue of an amendment to Article XXII of the Amazon Cooperation Treaty, the Organization of the Treaty of Amazon Cooperation was created with a view to further strengthening and ensuring the more effective implementation of the goals of the Treaty. The existence of an international legal entity directly regulated by public international law no doubt facilitates the realization of projects and can provide guidance for the rational utilization and sustainable management of shared water resources in the Amazon region.

Although the Amazon Cooperation Treaty does not prescribe a dispute, resolution mechanism, State Parties can agree to submit their disputes to an arbitral tribunal or a permanent judicial organ such as the ICJ. They can also resort to a political dispute-resolution method such as mediation or good offices. In any case, states are always bound by the customary obligation to negotiate a solution to their disputes in good faith.

\subsection{Transboundary water management in South America}

Unlike the practice in other regions of the world, discussions over shared water resources in South America, more often than not, take place under a cordial atmosphere. Although information exchange among states does take place in the region, the necessary data may be scattered around in different institutions, in which case its collection can prove quite burdensome. With reference to dispute resolution, South American states have been resolving their issues through direct negotiations, and in some cases, as between Argentina and Uruguay, through the ICJ. While progress has been made in terms of cooperation and knowledge over the management of shared surface water resources, this is not the case with regard to all shared groundwater. A first step forward has indeed been taken with regard to the Guarani Aquifer, but further in-depth knowledge is necessary to provide a more complete scenario of all the possible consequences of human action related to transboundary groundwater resources.

Currently, South American states do not appear to have an immediate interest in a universal framework treaty to regulate the management of their transboundary water resources. Rather, they would prefer to continue resorting to their existing bilateral and multilateral agreements and to applicable customary norms in the absence of such treaties. They also count on international organizations to help implement their preferred management regime, as is occurring in both the Amazon Basin and the Plate Basin.

This does not mean that the UNWC will have no value to South America. To the extent that the Convention codifies general international rules, its norms are binding on all states of the international community, including those of South America. In addition, the entry into force of the UNWC might foster the development of new customary norms in areas not yet covered by the existing regional treaties and could prove very influential in the interpretation of those particular treaties. 


\section{Richard Paisley and Taylor Henshaw ${ }^{6}$ on the 1997 UNWC from a North American perspective}

\subsection{Introduction}

The nations of North America - Canada, Mexico and the USA (see Figure 7) - share a significant number of international drainage basins and transboundary aquifers, comprising $16 \%$ of the world's transboundary river basins. The three countries have entered into various bilateral agreements with their neighbors for the management and allocation of their transboundary waters. However, while each voted in favor of the UNWC when it came before the UN General Assembly, none of them has ratified the instrument. The objective of this essay is to critically consider the absence of these three nations from the roll of the UNWC and to assess whether ratifying and implementing the UNWC would be in the individual and collective best interest of all three countries.

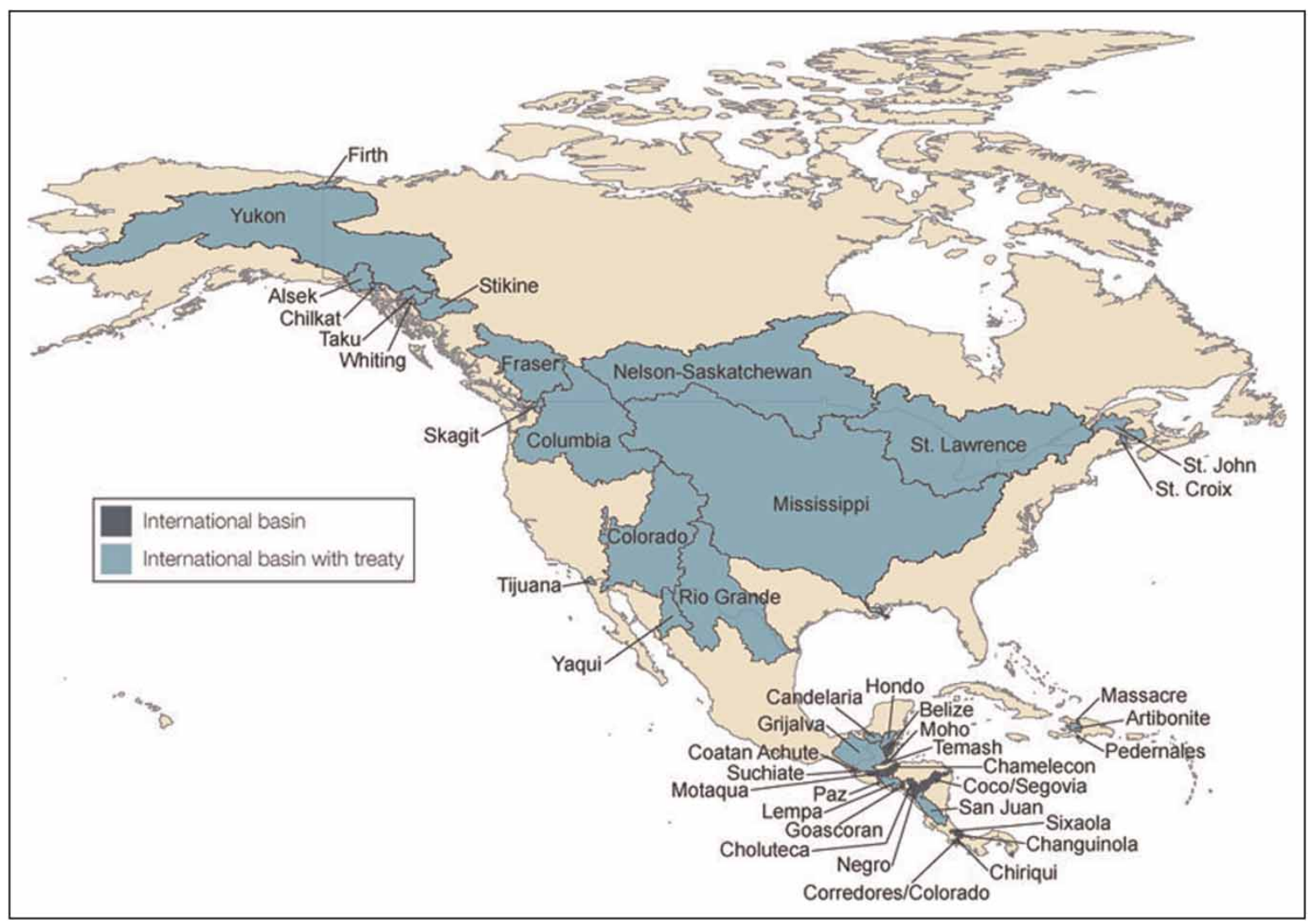

Fig. 7. Transboundary watercourse basins of North America. Source: UN Watercourses Convention Online Users Guide.

\footnotetext{
${ }^{6}$ Messrs Richard Paisley and Taylor Henshaw are with the Global Transboundary International Waters Governance Initiative at the University of British Columbia in Vancouver, Canada, which Mr Paisley directs. Mr Paisley can be reached at rpaisley@internationalwatersgovernance.com.
} 


\subsection{Perceptions}

The three nations appear to be in no great rush to ratify and implement the UNWC. This may be due to a perception that their international drainage basins are sufficiently managed without the UNWC: long-standing bilateral institutions have been established to deal with various aspects of the conservation and management of international drainage basins in North America.

Prominent among these mechanisms are the International Joint Commission (IJC) between Canada and the USA, and the International Boundary and Water Commission (IBWC) between Mexico and the USA. The history and practice of the IJC and the IBWC provide a rich body of work to review, which falls beyond the scope of this essay. Nevertheless, it is pertinent to mention some of the challenges the two commissions face, such as managing significant risks to water quality and quantity; the linking of border environments to binational trade and associated agreements; new stresses on public health and national economies; changes due to population growth and industrialization; greater demands on shared resources; increasing emphasis on public and indigenous peoples' participation in decision-making; greater value placed on non-traditional water uses, such as 'in stream' flows; and the imperative to establish ecosystem and active adaptive management approaches to resource management.

In addition, both institutions have experienced recent changes to their constituencies with the increasing influence of environmentalists and economic, social justice, and sustainable development advocates. As a result, ratification and implementation of the UNWC could help make both the IJC and the IBWC more relevant by increasing the focus on, and energy devoted to, the more sustainable conservation and management of transboundary waters and related resources in all three countries.

\subsection{Substantive objections}

Whether and the extent to which Canada, Mexico, and the USA have substantive objections to the UNWC are not well known. This may be because such objections are masked by the fact that all three countries were among not just the 103 countries who voted in favor of the UNWC, but also the 38 countries to officially sponsor the UNWC.

On reflection, various substantive reasons may exist to explain why none of the three countries are overly anxious to ratify and implement the UNWC. Mexico provides a good example. On the one hand, Mexico probably favors the UNWC, in part, because the Convention provides a basis for cooperating over measures to prevent, reduce and control pollution, including from the USA, which is an issue of great sensitivity to Mexicans. On the other hand, groundwater is tremendously important for Mexico where many believe that the conservation and management of shared transboundary aquifers necessitate a different international legal regime to that presented in the UNWC. More specifically, Mexico could be disinclined to ratify and implement the UNWC until more clarity is provided regarding the relationship between the UNWC and the emerging Draft Articles on the Law of Transboundary Aquifers. According to Stephen McCaffrey (McCaffrey, 2009), such clarity, regrettably, may be a long way off and

'will crucially depend on eliminating both the overlap between the draft and the UN Convention in terms of the physical subject matter they regulate, and the notion of "sovereignty" over shared groundwater, which should have no place in any set of rules governing the use, protection, and management of shared freshwater resources'. 


\subsection{Constitutional politics}

At the political level, the ratification and implementation of international treaties have become an increasingly challenging undertaking in all three countries.

In Canada, the negotiation, signing, and ratification of international treaties are controlled by the executive branch of the federal government. However, many international treaties, such as the UNWC, deal with matters that fall under the provincial sphere of legislative jurisdiction pursuant to the division of powers in Canada between the federal government, the provincial governments, and First Nations (Sections 91, 92, 92A and 35 of the Canadian Constitution) (Constitution of Canada website: http://laws-lois.justice.gc.ca/eng/const/). Also, according to Professor Emeritus of Economics and Forestry at the University of British Columbia, Peter Pearse (Pearse, 1994),

'A recurrent question in discussions about water management in Canada is "What is the role of the federal government?" A stranger to these discussions might think, naively, that this is simply a constitutional question. But even a good constitutional lawyer can not give a crisp answer. To some extent the question is a political one - "What does the federal government think its role is, at the moment?" This changes.'

As a practical matter, this means that ratification and implementation of the UNWC in Canada would likely trigger challenging and hard-nosed fiscal and other negotiations among the federal, provincial, and First Nations levels of government. An analogous situation occurred when Canada was asked to ratify and implement the Espoo Convention on Environmental Impact Assessment in a Transboundary Context (Espoo Convention).

In the USA, the legal situation regarding international treaties is somewhat different, but possibly even more challenging. Under United States constitutional law, an international 'treaty' is an agreement that has received the 'advice and consent' of two-thirds of the United States Senate and has been ratified by the President (Kirgis, 1997). As a practical matter, given the increasing political polarization within the United States Senate, obtaining the consent of two-thirds of Senate members for any multilateral treaty, including the UNWC, would be exceedingly challenging.

Mexico is much closer to Canada constitutionally than to the USA, as Mexico constitutionally allocates separate and exclusive spheres of authority to the states/provinces and the federal government. International treaties must conform to the Mexican Constitution in order to be valid. However, many international treaties address topics that in Mexico fall within the exclusive authority of the states/provinces. Seemingly, in practical terms, this means that Mexico may need to enact domestic legislation to transform international treaty obligations into enforceable domestic law, which could be both time-consuming and expensive.

\subsection{Champions}

Another reason why the UNWC has not yet been ratified and implemented in Canada, Mexico, and the USA is the paucity of champions at the political level in all three countries. This resonates with Niccolo Machiavelli's observation in The Prince (Machiavelli, 1532):

'there is nothing more difficult to take in hand, more perilous to conduct, or more uncertain in its success, than to take the lead in the introduction of a new order of things. Because the innovator 
has for enemies all those who have done well under the old conditions, and lukewarm defenders in those who may do well under the new. This coolness arises partly from fear of the opponents, who have the laws on their side, and partly from the incredulity of men, who do not readily believe in new things until they have had a long experience of them.'

\subsection{Justifying the UNWC in North America}

Despite the apparent obstacles noted above, there are at least three compelling reasons why Canada, Mexico, and the USA should immediately ratify and implement the UNWC. First, ratification and implementation will send a strong and important message to each other, and to the world community, generally, that sovereign states have important rights and responsibilities when it comes to transboundary freshwater resources.

Second, the fact that Canada and the USA are variously both upstream and downstream of each other and that the USA is upstream of Mexico will particularly and importantly help dispel any lingering misconception that the UNWC may be biased in favor of downstream or upstream states.

Third, Canadian, Mexican, and American support for the Convention could not be more timely, given how the world community is currently struggling with the harsh realities of climate change and water scarcity.

Ratifying and implementing the UNWC in North America would also demonstrate a wider acceptance of practice under the Convention as representing customary international law. In turn, this could place the UNWC higher on various political agendas and could help lead to a more stable framework for transboundary water cooperation globally.

\section{Dr Salman M.A. Salman and Professor Gabriel Eckstein ${ }^{7}$ : concluding thoughts on the implications of the entry into force of the United Nations Watercourses Convention}

The preceding essays discussing and analyzing various perspectives on, and interpretations of, the UNWC convey different, and sometimes conflicting, views and perceptions about the various principles set forth in the Convention. Indeed, many of these differences arose in the very early years of the work of the UNILC on the draft Convention, which began in 1971, and continued throughout to its conclusion in 1994. These differences also dominated the two meetings of the UN Sixth Committee convened as a Working Group of the Whole in 1996 and 1997, as well as the UN General Assembly meeting on 21 May 1997, which finalized and approved the Convention. Thus, the journey of the Convention over the past 44 years has been quite turbulent and contentious.

As evident in the perspectives from Southern Africa and the Nile Basin, one of the most contentious debates surrounds the relationship between the principle of equitable and reasonable utilization and the

\footnotetext{
${ }^{7}$ Dr Salman is an academic researcher and consultant on water law and policy, and editor-in-chief of Brill Research Perspectives, International Water Law. Until 2009, Dr Salman served as Lead Council and Water Law Adviser for the World Bank. He can be reached at salmanmasalman@gmail.com. Professor Eckstein is a member of the law faculty at Texas A\&M University, director of the International Water Law Project, and editor of the International Water Law Project Blog. He can be reached at gabrieleckstein@law.tamu.edu.
} 
obligation against causing significant harm between upper and lower riparians. As evidenced in the essays, this issue remains a focal area of debate, notwithstanding the efforts made to clarify the issue during the Sixth Committee and UNGA meetings, and through the interpretations and elaboration of the International Court of Justice in the Gabčikovo-Nagymaros and the Pulp Mills cases. A number of lower riparian countries still view the Convention as biased in favor of upper riparians because it subordinates the obligation against causing harm to the principle of equitable and reasonable utilization. Conversely, many upper riparians still believe that the Convention favors lower riparians because of its separate mention of the obligation against causing harm. It is noteworthy that the three countries that voted against the Convention (Burundi, China, and Turkey), and many of those that abstained, such as Bolivia, Ethiopia, Mali, and Tanzania, are largely upper riparian states. On the other hand, a number of lower riparians, such as Egypt and Pakistan, and those with mixed upper and lower riparian geographies, including France and Peru, also abstained, concerned that the Convention favors upstream riparians because it subordinates the no harm rule to the principle of equitable and reasonable utilization. Of all these countries, only France is now a party to the Convention.

Although the SADC countries amended their Protocol on Shared Watercourses in 2000 to make it consistent with the Convention, they tried to maintain parity between the two principles by subjecting each to the other, thus keeping the actual relationship in abeyance and unresolved. The same concerns seem to be a main reason for the South Asia countries' reluctance to join the Convention.

It is true that the Convention does indeed subordinate the obligation against causing harm to the principle of equitable and reasonable utilization. Yet this should in no way be taken to indicate a bias in favor of upper riparians. The principle grants each riparian a fair share for utilization, based, at least theoretically, on some objective and widely accepted principles dating back to the Helsinki Rules of 1966 (Helsinki Rules on the Uses of the Waters of International Rivers (with comments), International Law Association, 1966). The ICJ, in addition to buttressing and elaborating the principle of equitable and reasonable utilization, confirmed, in the Gabčikovo-Nagymaros case, the perfect equality of all riparian states in the uses of the watercourse, and the exclusion of any preferential privilege of one riparian state in relation to the others. The ICJ noted that modern development of international law has strengthened this principle for non-navigational uses of international watercourses 'as evidenced by the adoption of the Convention of 21 May 1997 on the Law of the Non-Navigational Uses of International Watercourses by the United Nations General Assembly'. The ICJ reconfirmed this elaboration in 2010 in the Pulp Mills case.

The interaction of the Convention with existing agreements seems to be another matter raising the concerns of some states, as noted in the perspectives from South America, North America, Southern Africa, and to some extent Central Asia. Article 3 of the Convention asserts that it does not affect the rights or obligations of watercourse states arising from agreements already in force. Nonetheless, it asks the parties to consider, where necessary, harmonizing such agreements with the basic principles of the Convention. Some riparian states with existing bilateral or regional agreements appear to believe that the harmonization formulation causes those prior agreements to be weakened, if not disregarded. Conversely, riparian states left out of existing local and regional agreements criticize the Convention for not subjecting existing agreements to the Convention's provisions and failing to mandate inclusion of all riparians in such agreements. Both perspectives misconstrue the Convention. A close reading reveals that the Convention recognizes the validity of existing agreements as well as the rights of riparian states in a shared watercourse that are not parties to such local and regional agreements. This is the interpretation described in the essay discussing the European perspective, which also acknowledges the complementary nature of a general framework instrument, like the Convention, and more specific bilateral and regional agreements. 
A third contentious issue, raised most prominently in the essays presenting the Chinese and South Asian perspectives and suggested in the South American perspective, relates to the Convention's dispute-settlement provisions. While some states, such as Pakistan, believe that the provisions are too weak because they do not mandate a binding mechanism, other states, such as China, interpret the fact-finding procedures as being compulsory and argue that such an approach interferes with their sovereign right to select their own approach to dispute settlement. Indeed, Article 33 of the Convention offers parties a number of methods for settling disputes. However, the only obligatory process set forth is impartial fact-finding and a requirement to consider the fact-finding report in good faith. Thus, while the Convention provides a basic mechanism for ascertaining the facts of a dispute, it leaves the precise method for resolving disputes to the parties. Given that the Convention is a framework treaty, this is clearly a reasonable approach, incorporating both points of view.

A fourth concern regards the Convention's relevance to groundwater resources. As explained in the essays providing the South Asian and North American perspectives, some countries, such as Mexico and Pakistan, question whether the Convention's regime should extend to subsurface waters. The unease appears to be based, in part, on inadequate national information related to border-region aquifers and the extent to which the Convention could fully address groundwater challenges, which often are distinct from those affecting surface waters. The Convention, however, provides mechanisms for developing knowledge about hydraulically related water resources, including obligations to cooperate (Article 8) and share information (Article 9), and even to generate new knowledge (Article 9). Furthermore, it would be illogical to impose the Convention's regime on water resources whose relations to a transboundary watercourse are still unclear. Nevertheless, with the advent of the Draft Articles on Transboundary Aquifers, which contain a number of noteworthy groundwater-specific provisions, countries may be justified in raising questions regarding how the Convention addresses groundwater resources. However, the issue should be couched more in terms of a concern rather than a contentious matter preventing ratification of the Convention.

Notwithstanding the regional and subject-specific challenges and concerns, there is a clear consensus that transboundary waters should be managed on the basis of cooperation and the equality of all riparians in the use of shared watercourses. Beyond these basic international law tenets, there are a number of advantages that could accrue to nations that ratify the Convention. Foremost is the comfort and security of knowing that riparian neighbors operate from the same foundational norms.

For example, under the Convention, all riparians - regardless of whether upstream or downstream must abide by the instrument's detailed notification procedures before embarking on measures that may affect an international watercourse. The Convention does not bestow a veto right on any riparian, but rather requires interaction and communication in conformity with fundamental norms of international law. As a result, riparians are prevented from taking unilateral action and are encouraged to cooperate through various means, including notification.

The notification procedures can also benefit states to the extent that they offer greater certainty, security and comfort to the various international, regional, and national financial institutions about financing projects affecting international watercourses. Agencies such as regional development banks and state development agencies, which typically lack such procedures, now have a global instrument on which to rely for project notification and processing.

Ultimately, as suggested in Dr McCaffrey's essay in part one of this report, the Convention's most significant value lies in its status as an authoritative statement of customary international water law and a framework under which more specific bilateral and regional agreements can be established and 
interpreted. In fact, the UNGA itself used the term 'codification' when it referred the task of preparing the draft convention to its legal arm, the UNILC.

Hence, entry into force of the Convention represents a broadening commitment by the international community to manage and utilize transboundary freshwater resources through peaceful and cooperative means. Entry into force is also likely to have a 'snowball' effect of creating an incentive for other states to join, as happened with other treaties, because few states would want to be left out.

Frontier freshwater resources have long been one of the few transboundary natural resources devoid of a global framework treaty. With the UNWC, freshwater resources no longer carry that distinction. Indeed, a new chapter of international cooperation over these resources has emerged.

\section{References}

Agreement constituting the Tri-National Commission of the Pilcomayo River Basin, La Paz, Bolivia, 2 September 1995. Available at http://faolex.fao.org/docs/pdf/mul16756.pdf.

Agreement on the Guaraní Aquifer, San Juan, Argentina, 2 August 2010. Available at http://www.parlamento.gub.uy/htmlstat/ pl/pdfs/repartidos/senado/S2012030486-00.pdf.

Chen, H., Rieu-Clarke, A. \& Wouters, P. (2013). Exploring China's transboundary water treaty practice through the prism of the UN Watercourses Convention. Water International 38(2), 217-230. Available at http://www.tandfonline.com/doi/full/10. 1080/02508060.2013.782134\#.U-tj-9JH4rV.

China Water Risk website: Big Picture. Available at http://chinawaterrisk.org/big-picture/.

China 2014 No.1 Doc: Arable Land, Food \& Water. Available at http://chinawaterrisk.org/notices/2014-no-1-doc-arable-landfood-and-water/.

Clark, P. (2014). Troubled waters: the Mekong river crisis. Financial Times Magazine, 18 July 2014. Available at http://www. ft.com/intl/cms/s/2/1add7210-0d3d-11e4-bcb2-00144feabdc0.html\#slide0.

Cohen, D. (2014). Xi Woos Modi With 'Peace Through Development' Approach, China Brief, 14(14), 17 July 2014. Available at http://www.jamestown.org/programs/chinabrief/single/?tx_ttnews\%5Btt_news\%5D=42638\&tx_ttnews\%5BbackPid\% 5D=25\&cHash=beaecb4bbb6a9cfe5f146629dc8c0d97\#.U-tmHdJH4rW.

Convention on Biological Diversity; in force 29 December 1993. Available at http://www.cbd.int/.

Convention on Environmental Impact Assessment in a Transboundary Context (Espoo Convention). Signed in 1991; in force 10 September 1997. Available at http://www.unece.org/env/eia/eia.html.

Convention on Wetlands of International Importance (RAMSAR Convention); in force 21 December 1975. Available at http:// www.ramsar.org/cda/en/ramsar-home/main/ramsar/1_4000_0_.

Eckstein, G. (2005). A hydrogeological perspective of the status of ground water resources under the UN watercourse convention. Columbia Journal of Environmental Law 30, 525-564. Available at http://ssrn.com/abstract=899142.

Eckstein, G. (2011). Managing buried treasure across frontiers: the international law of transboundary aquifers. Water International 36(5), 573-583. Available at http://ssrn.com/abstract=1924469.

Eckstein, G. \& Sindico, F . (2014) The law of transboundary aquifers: many ways of going forward, but only one way of standing still. Review of European Community \& International Environmental Law 3(1), 32-42. Available at http://ssrn.com/ abstract $=2429569$.

Gabčikovo-Nagymaros Project case (Hungary/Slovakia) (ICJ) (1997). Available at http://www.icj-cij.org/docket/index.php? p1=3\&p2=3\&case $=92$.

Helsinki Rules on the Uses of the Waters of International Rivers (with comments), International Law Association (1966). Available at http://www.internationalwaterlaw.org/documents/intldocs/Helsinki_Rules_with_comments.pdf.

International Groundwater Resources Assessment Centre (IGRAC), Transboundary Aquifers of the World - Updated 2012. Available at http://www.un-igrac.org/dynamics/modules/SFIL0100/view.php?fil_Id=213.

Kirgis, F. L. (1997). International Agreements and U.S. Law, ASIL Insights, 2(5) (27 May 1997). Available at http://www.asil. org/insights/volume/2/issue/5/international-agreements-and-us-law.

Machiavelli, N. (1532). The Prince. Available at http://www.gutenberg.org/files/1232/1232-h/1232-h.htm. 
Malzbender, D. \& Earle, A. (2013). Southern Africa. In: The UN Watercourses Convention in Force: Strengthening International Law for Transboundary Water Management. Rocha Loures, F. \& Rieu-Clarke, A. (eds), Routledge, pp. 112122. Available at http://www.routledge.com/books/details/9781849714464/.

Margat, J. \& van der Gun, J. (2013). Groundwater Around the World: A Geographic Synopsis. Available at http://www. crcpress.com/product/isbn/9781138000346.

McCaffrey, S. (2001). The contribution of the UN convention on the law of the non-navigational uses of international watercourses. International Journal of Global Environmental Issues 1(3/4), 250-263. Available at http://internationalwaterlaw. org/bibliography/IJGEI/03ijgenvl2001v1n34mccaffrey.pdf.

McCaffrey, S. (2009). Current developments: the international law commission adopts draft articles on transboundary aquifers. The American Journal of International Law 103, 272-293. Available at http://www.aida-waterlaw.org/PDF/McCaffrey-TBAqs.pdf.

Ministry of Foreign Affairs of China (2014). Xi Jinping Delivers Important Speech at National Congress of Brazil - Carry Forward Traditional Friendship and Jointly Open up New Chapter of Cooperation, 17 July 2014. Available at http://www.fmprc. gov.cn/mfa_eng/zxxx_662805/t1176214.shtml.

Pearse, P. H. (1994). Development of Federal Water Policy: One Step Forward, Two Steps Back: Key Note Address at the Canadian Water and Wastewater Association National Management Seminar, Calgary, Alberta, 1994.

Pulp Mills on the River Uruguay (Argentina v. Uruguay) (ICJ) (2010). Available at http://www.icj-cij.org/docket/index.php? $\mathrm{p} 1=3 \& \mathrm{p} 2=3 \&$ code $=$ au $\&$ case $=135 \& \mathrm{k}=88$.

Ramachandran, S. K. \& Krishnan, A. (2014). China agrees to extend provision of hydrological data. The Hindu, 1 July 2014. Available at http://www.thehindu.com/news/international/world/china-agrees-to-extend-provision-of-hydrological-data/article6164121.ece.

Revised Protocol on Shared Watercourses (Protocol) of the Southern African Development Community (SADC), Windhoek, 7 August 2000. Available at http://www.internationalwaterlaw.org/documents/regionaldocs/Revised-SADC-Shared Watercourse-Protocol-2000.pdf.

Rieu-Clarke, A. (2007). Entry into force of the 1997 UN Watercourses Convention: Barriers, Benefits and Prospects. Water 21, 12-16. Available at http://www.iwapublishing.com/pdf/Water21\%20Dec07p12to16.pdf.

Rieu-Clarke, A. \& Rocha Loures, F. (2009). Still not in Force: Should States Support the 1997 UN Watercourses Convention? Review of European Community \& International Environmental Law 18(2), 185-197. Available at http://onlinelibrary.wiley. com/doi/10.1111/j.1467-9388.2009.00640.x/abstract.

Salman, S. M. A. (2001). Legal Regime for Use and Protection of International Watercourses in the Southern African Region: Evolution and Context. Natural Resources Journal 41, 981-1022. Available at http://www.salmanmasalman.org/wp-content/ uploads/2012/12/SADCarticle2.pdf.

Statute of the River Uruguay. Signed at Salto, Uruguay on 26 February 1975. Available at http://internationalwaterlaw.org/ documents/regionaldocs/Uruguay_River_Statute_1975.pdf.

Ti Le-Huu \& Lien Nguyen Duc in cooperation with Apichart Anukularmphai et al. (2003). Mekong Case Study, PCCP Series No. 10, UNESCO-IHP. Available at http://unesdoc.unesco.org/images/0013/001332/133290e.pdf.

Transboundary Freshwater Dispute Database Oregon State University (2014). Available at http://www.transboundarywaters. orst.edu/database/register/maps/South\%20America\%20Basins.jpg.

Treaty for Amazonian Cooperation. Concluded at Brasilia on 3 July 1978. Available at https://treaties.un.org/doc/Publication/ UNTS/Volume\%201202/volume-1202-I-19194-English.pdf.

Treaty of the River Plate Basin. Signed at Brasilia on 23 April 1969. Available at https://treaties.un.org/doc/Publication/UNTS/ Volume\%20875/volume-875-I-12550-English.pdf.

UNECE Convention on the Protection and Use of Transboundary Watercourses and International Lakes, 17 March 1992 ; in force 6 October 1996. Available at http://www.unece.org/env/water/text/text.html.

UN Convention to Combat Desertification; in force 26 December 1996. Available at http://www.unccd.int/en/Pages/default. aspx.

UN Framework Convention on Climate Change; in force 21 March 1994. Available at http://newsroom.unfccc.int/.

UN General Assembly Press Release GA/9248, 21 May 1997. Available at http:/www.internationalwaterlaw.org/documents/ intldocs/convention_press.html.

UN General Assembly Resolution 2669, Progressive Development and Codification of the Rules of International Law relating to International Watercourses (21 July 1971). Available at http://internationalwaterlaw.org/documents/intldocs/UNGA_1970_ resolution_2669_(XXV)_on_progressive_development_and\%20codification.pdf. 
UN General Assembly Sixth Committee, United Nations General Assembly 51st Session, Summary of the Record of the 15th Meeting of 8 October 1996. Available at http://www.un.org/ga/search/view_doc.asp?symbol=a/c.6/51/sr.15.

UN International Law Commission, Resolution on Confined Transboundary Groundwater, in Yearbook of the International Law Commission, 1994, vol. II (Part Two). Available at http://legal.un.org/ilc/texts/instruments/english/draft\%20articles/ 8_3_1994_resolution.pdf.

UN Watercourses Convention Online Users Guide website: Importance - The Legal Architecture for Transboundary Waters. Available at http://www.unwatercoursesconvention.org/importance/the-legal-architecture-for-transboundary-waters/.

Wouters, P. \& Chen, H. (2011). China's 'soft-path' to transboundary water cooperation examined in the light of two UN Global Water Conventions: exploring the 'Chinese way'. Journal of Water Law 22(6), 229-247.

YouTube (2014). Xi Jinping delivers speech at the National Congress of Brazil, 18 July 2014. Available at https://www.youtube.com/watch? $\mathrm{v}=3 \mathrm{Wjbz}$ PsyLZY.

Yushan, D. (2014). Xinhua English News, 25 July 2014. Available at http://news.xinhuanet.com/english/indepth/2014-07/25/ c_133510785.htm. 